tháng) và 23 bệnh nhân ghép thận (thời gian trung bình sau ghép 51,3 tháng, thời gian lọc máu trung bình trước ghép 22, 8 tháng) thấy tỷ lệ nang thận ở bệnh nhân lọc máu chu kỳ là $49 \%$, trong khi đó ở nhóm bệnh nhân sau ghép thận, tỷ lệ nang thận chủ là $17 \%$.

Về một số yếu tố liên quan, nghiên cứu của chúng tôi cho thấy tỷ lệ nang thận tăng dân theo tuổi và thời gian lọc máu trước khi ghép thận trong khi không có sự khác biệt giữa nam và nữ. Kết quả này là tương đồng với kết quả của các nghiên cứu trước đây. Theo nghiên cứu của nhiều tác giả, ở người bình thường, tỷ lệ nang thận gia tăng theo lứa tuổi. Bệnh hay gặp ở lứa tuổi trên 40, hiếm khi gặp ở lứa tuổi trước 20. Khoảng $25 \%$ người trên 40 tuổi và $50 \%$ người trên 50 tuổi có nang đơn thận và có tới trên $90 \%$ ở những người trên 70 tuổi. Theo nhiều tác giả tỷ lệ nang thận mắc phải sẽ tăng lên theo thời gian lọc máu. Choyke và cộng sự (2000) cho thây sau 3 năm lọc máu chu kỳ có khoảng 10\%-20\% bệnh nhân phát triển nang thận mắc phải, và sau 5 năm lọc máu tỉ lệ là $40 \%-60 \%$ và sau 10 năm thì có hơn $90 \%$ mắc nang thận mắc phải. Tuy nhiên, kết quả về liên quan giữa tỷ lệ nang thận với giới tính còn có sự khác biệt nhất định so với nghiên cứu trước đây. Trương LD và cộng sự (2003) nhận thấy tỷ lệ mắc nang thận mắc phải ở nam giới gấp 3 lần nữ giới. Chúng tôi cho rằng sự khác biệt này cần được đánh giá với số lượng cớ mẫu lớn hơn và thời gian theo dõi dài hơn.

\section{KẾT LUẬN}

Tỷ lệ nang thận mắc phải của thận chủ sau ghép là $8,7 \%$. Tỷ lệ nang tăng dần theo thời gian lọc máu trong khi không có sự khác biệt về giới tính, thời gian sau ghép, chức năng thận ghép, loại thuốc chống thải ghép.

\section{TÀI LIỆU THAM KHẢO}

1. John T. Daugirdas (2015), "Handbook of Dialysis".

2. Almirali J., et al. (1990), "Renal cell carcinoma and acquired cystic kidney disease after renal transplantation", Transpl Int, 3(1), 49.

3. Foshat M., Eyzaguirre E. (2017), "Acquired Cystic Disease-Associated Renal Cell Carcinoma: Review of Pathogenesis, Morphology, Ancillary Tests, and Clinical Features", Arch Pathol Lab Med, 141(4), 600-606.

4. Phan Thị Xuân Hương (2000), "Nghiên cứu đăc điểm nang thận đơn thuân ở người lớn qua siểu âm", Luận văn tốt nghiệp bác sỹ chuyên khoa cấp II, Đại học Y Hà Nội.

5. Nguyễn Văn Tú (2020), "Nghiên cứu đặc điểm thiếu máu của bênh nhân trước và sau ghép thận", Luận văn thạc sỹ Y học, Học Viện Quân Y.

6. Cheung C. Y., et al. (2011), "Renal cell carcinoma of native kidney in Chinese renal transplant recipients: a report of 12 cases and a review of the literature", Int Urol Nephrol, 43(3), 675-80.

7. Trân Ngọc Sinh (2000), "Suy nghĩ qua theo dõi các trường hợp ghép thận tại Trung Quốc", Kỷ yếu công trình 1992-2000, Hội nghị tổng kết chương trình ghép thận, Bệnh viện Chợ Rấy, tr. 76-79.

8. Filocamo M. T., et al. (2009), "Renal cell carcinoma of native kidney after renal transplantation: clinical relevance of early detection", Transplant Proc, 41(10), 4197-201.

\title{
MÔ TẢ ĐẶC ĐIỂM LÂM SÀNG, GIẢI PHẪU BÊ̂NH TRONG ĐIỀU TRI PHẪU THUÂ̂T UNG THƯ BIỂU MÔ TRỰC TRÀNG
}

\section{TÓM TẮT}

Mục tiêu: Mô tả đă̆c điểm lâm sàng và giải phẫu bệnh trong điều trị phấu thuật ung thư biểu mô trực tràng tại trung tâm phẫu thuật Đaai trực tràng - tâng sinh mồn, bệnh viện Hữu nghị Việt Đức. Đối tượng và phương pháp: nghiên cứu mồ tả cắt ngang trên 109 bệnh nhân được chẩn đoán UTBMTT được điêu trị

\section{${ }^{1}$ Bênh viên $K$ \\ ${ }^{2}$ Bệnh viện Việt Đức \\ ${ }^{3}$ Họ viến Quân $Y$}

Chịu trách nhiệm chính: Nguyễn Minh Trọng

Email: drtrong81@gmail.com

Ngày nhận bài: 17.5.2021

Ngày phản biên khoa họ: 16.6.2021

Ngày duyệt bài: 28.6.2021

\section{Nguyễn Minh Trọng ${ }^{1}$, Phạm Hoàng Hà ${ }^{2}$, Nguyễn Xuân Hùng ${ }^{2}$, Tống Đức Minh $^{3}$}

phẫu thuật tại Trung tâm phẫu thuật Đại trực tràng Tâng sinh môn, bệnh viện Hữu nghị Việt Đức từ 10/2016 đến 05/2019. Kết quả: Tuổi trung bình mắc ung thư trực tràng là $63,48 \pm 12,22$ (tuổi), chủ yếu là nam giới chiếm $66,97 \%$; độ tuổi chiêm tỳ lê cao nhất là từ 60 - 69 với 33,94\%. Lý do vào viện do đại tiện nhây máu $(82,57 \%)$ là chủ yếu. Thời gian trung bình phát hiện bệnh là 3,72 \pm 4,20 (tháng), đa số bệnh nhân được phát hiên bênh sớm trong 3 tháng đâuu chiếm $66,06 \%$. Triệu chứng đại tiện nhày máu chiếm $90,83 \%$, gây sút cấn chiếm $39,45 \%$. Tổn thương giải phẫu bệnh đại thể dạng loét sùi $(40,37 \%)$, thể UTBM tuyến $(87,16 \%)$ chiếm chủ yếu, phần lớn UTTT có đô biệt hóa vừa $(83,49 \%)$. Hơn $50 \%$ chưa có di căn hạch vùng $(59,63 \%)$. Mức độ xâm lấn khối U ở giai đoạn T3 chiếm tỷ lệ $68,80 \%$. Kết luận: Tỷ lệ mắc UTTT chủ yếu là nam giới, tuổi trung bình là $63,48 \pm 12,22$ 
(tuổi). Lý do vào viện do đại tiện nhây máu $(82,57 \%)$ chiếm chủ yếu. Thời gian phát hiện bệnh chủ yếu trong 3 tháng đầu. Triệu chứng đại tiện nhày máu $90,83 \%)$, gây sút cân $(39,45 \%)$. Tổn thương giải phẩu bệnh dạng loét sùi $(40,37 \%)$, thể UTBM tuyến $(87,16 \%)$ chiểm chủ yếu, phân lớn UTTT có độ biệt hóa vừa $(83,49 \%)$. UTTT chưa có di căn hạch vùng (59,63\%). Mức độ xâm lấn khối U ở giai đoạn T3 chiếm tỷ lệ chủ yếu $(68,80 \%)$.

Tư khóa: Đặc điểm lâm sàng, đặc điểm giải phẫu bệnh, ung thư trực tràng.

\section{SUMMARY}

\section{CLINICAL AND HISTOPATHOLOGICAL} CHARACTERISTICS OF RECTAL CANCER PATIENTS

Objectives: Describing clinical and histopathological characteristics of rectal cancer patients at Viet Duc hospital. Subjects and methods: The descriptive cross-sectional study on 109 patients diagnosed rectal carcinoma and surgical treatment at Department of colorectal and perineal surgery, Viet Duc hospital from October, 2016 to May, 2019. Results: The average age of rectal cancer was $63.48 \pm 12.22$ (years old), mainly male, accounting for $66.97 \%$; age group accounted for the highest proportion was from 60 - 69 with 33.94\%. The main reason admitted hospital was bloody defecation $(82.57 \%)$. The average time to detect the disease was $3.72 \pm 4.20$ (month), mainly patients with early detection of the disease in the first 3 months accounted for $66.06 \%$. Mainly, patients had symptoms of bloody defecation, accounting for $90.83 \%$, weight loss accounted for $39.45 \%$. Mass-ulcer type (40.37\%), rectal adenocarcinoma type $(87.16 \%)$ accounted for the main proportion, most tumors had a medium differentiation $(83.49 \%)$. Most had not had regional lymph node metastasis (59.63\%). The invasive stage of T3 rectal cancer accounted for the main proportion $(68.80 \%)$. Conclusion: The prevalence of rectal cancer was mainly male, the average age was $63.48 \pm$ 12.22 (age). The main reason admitted hospital was bloody defecation $(82.57 \%)$. The time to detect the disease was mainly in the first 3 months. Symptoms of bloody defecation (90.83\%), weight loss (39.45\%). Mass-ulcer type $(40.37 \%)$, rectal adenocarcinoma type $(87.16 \%)$ accounted for the main proportion, most tumors had a medium differentiation (83.49\%). Rectal cancer without regional lymph node metastasis $(59.63 \%)$. The invasive stage of T3 rectal cancer accounted for the main proportion (68.80\%).

$$
\text { Keywords: clinical cha }
$$

histopahologicalcharcteristics, rectal cancer.

\section{I. ĐĂT VẤN ĐỀ}

Theo GLOBOCAN 2018, ghi nhận tỷ lệ mắc mới ung thư trực tràng (UTTT) là 704.376 trường hợp (chiếm 3,9\% số trường hợp mắc mới các loại ung thư') và và có tới 310.394 trường hợp tử vong (chiếm 3,2\% tổng số trường hợp tử vong do các loại ung thư) [6]. UTTT có những đặc điểm lâm sàng và giải phẫu bệnh tương đồng với ung thư ở các vị trí khác trong đại tràng, tuy nhiên với đặc điểm là khối u nằm ở đoạn cuối đường ống tiêu hóa, UTTT có những biểu hiện lâm sàng và đặc điểm giải phẫu bệnh riêng, khác với các loại ung thư ở vị trí khác của đại tràng. Do vậy, chúng tôi thực hiện nghiên cứu này nhằm mục tiêu: "Mô tả đặc điểm lâm sàng và giải phẫu bệnh trong điều trị phẫu thuật ung thư biêu mô trực tràng tại bệnh viện Hĩ̛u nghị Việt Đức".

\section{II. ĐỐI TƯợNG VÀ PHƯƠNG PHÁP NGHIÊN CứU}

1. Đối tượng nghiên cứu. Gồm 109 bệnh nhân được chẩn đoán UTBMTT được điêu trị tại Trung tâm phẫu thuật Đại trực tràng - Tâng sinh môn, bệnh viện Hữu nghị Việt Đức từ 10/2016 đến 05/2019.

Tiêu chuẩn lựa chọn. Bênh nhân được chẩn đoán xác định ung thư biểu mô trực tràng (nội soi có kết quả sinh thiết khẳng định ung thư biểu mô trực tràng); Đánh giá giải phẫu bệnh sau mổ.

Tiêu chuẩn loại trừ. Ung thư đường tiêu hóa khác, không phải ung thư biểu mô trực tràng; Bệnh nhân ung thư trực tràng di căn xa; Không đẩy đủ kết quả giải phẩu bệnh sau mổ.

\section{Phương pháp nghiên cứu}

Thiết kế nghiên cứu: Nghiên cứu mô tả cắt ngang.

Chỉ tiêu nghiên cứu:

Tuổi:, đơn vị tính: năm tuổi. Giới tính: gồm 2 nhóm giới tính: nam và nữ. Dựa trên kết quả nghiên cứu chia thành các nhóm tuổi: dưới 40 tuổi, từ 40 đến 49 tuổi, từ 50 đến 59 tuổi, từ 60 đến 69 tuổi, và từ 70 trở lên. Tính tỷ lệ phân trăm phân bố bệnh nhân theo nhóm tuổi, theo giới.

Thời gian từ khi có triệu chứng lâm sàng tới khi vào viện: Chia thành: dưới 3 tháng, từ 4 - 6 tháng, từ 7 - 12 tháng và trên 12 tháng.

Lý do vào viện, Triệu chứng lâm sàng khi vào viện: Tính tỷ lệ phân trăm số bệnh nhân theo các triệu chứng (\%).

Giải phẫu bệnh đánh giá đại thể khối u: dang sùi, dạng loét, dạng loét sùi, dạng thâm nhiếm, dạng polyp.

Đánh giá mức độ xâm lấn chiếm chu vi trực tràng, chia thành: dưới $1 / 4$ chu vi; từ $1 / 4$ - 1/2 chu vi; từ $1 / 2$ - 3/4 chu vi và chiếm toàn bộ chu vi.

Đánh giá vi thể khối ung thư trực tràng: dựa trên kết quả giải phẫu bệnh bao gôm ung thư biểu mô tuyến, ung thư biểu mô tuyến nhày, ung thư biểu mô tế bào nhẫn, ung thư biểu mô không biệt hóa, ung thư biểu mô thể vi nhú, ung thư biểu mô tuyến nhú, ung thư biểu mô tuyến răng cưa... Đánh giá mức độ biệt hóa: được chia 
thành: biệt hóa cao, biệt hóa vừa, biệt hóa ít và không biệt hóa. Đánh giá giai đoạn theo TNM: dựa theo AJCC 7th (American Joint Committee on Cancer) 2010 [7].

3. Phương pháp xử lý số liệu: số liệu thu thập được nhập và xử lý trên phẩn mềm thống kê y sinh học SPSS 22.0.

4. Đạo đức nghiên cứu: nghiên cứu không can thiệp trên bệnh nhân và không phục vụ cho mục đích thương mại.

\section{KẾT QUẢ NGHIÊN CỨU}

Tuổi trung bình mắc ung thư trực tràng là $63,48 \pm 12,22$ (tuổi), chủ yếu là nam giới chiếm $66,97 \%$; độ tuổi chiếm tỷ lệ cao nhất là từ 60 69 với 33,94\%, các bệnh nhân UTTT chủ yếu từ 60 tuổi trở lên $(71,55 \%)$. Trong nghiên cứu này, chúng tôi ghi nhận một số đặc điểm lâm sàng, giải phẫu bệnh các BN UTTT như sau:

\section{Bảng 1. Lý do vào viện}

\begin{tabular}{|c|c|c|}
\hline Lý do & $\begin{array}{c}\text { Số lượng } \\
(\mathbf{n})\end{array}$ & $\begin{array}{c}\text { Tỷ lề } \\
\mathbf{( \% )}\end{array}$ \\
\hline Đau bụng & 6 & 5,50 \\
\hline Đại tiện nhầy máu & 90 & 82,57 \\
\hline Gầy sút cân & 1 & 0,92 \\
\hline Thay đối thói quen đi ngoài & 1 & 0,92 \\
\hline Rối loạn tiêu hóa & 1 & 0,92 \\
\hline Cảm giá nặng hậu môn & 2 & 1,83 \\
\hline Đi ngoài khó & 6 & 5,50 \\
\hline Khám định kỳ phát hiện & 1 & 0,92 \\
\hline Chảy máu sau mố trĩ & 1 & 0,92 \\
\hline Tống & $\mathbf{1 0 9}$ & $\mathbf{1 0 0}$ \\
\hline
\end{tabular}

Nhân xét: Chủ yếu bênh nhân đến viện với lý do đại tiện nhầy máu (82,57\%).

Bảng 2. Thời gian mắc bệnh và thời gian nằm viện

\begin{tabular}{|c|c|c|}
\hline Thời gian mắc bệnh & $\begin{array}{c}\text { Số lươơng } \\
(\mathbf{n})\end{array}$ & $\begin{array}{c}\text { Tỷ lệ } \\
(\mathbf{\%})\end{array}$ \\
\hline$\leq 3$ tháng & 72 & 66,06 \\
\hline từ $>3-6$ tháng & 20 & 18,35 \\
\hline từ $>6-12$ tháng & 12 & 11,01 \\
\hline$>12$ tháng & 5 & 4,59 \\
\hline Tống & 109 & 100 \\
\hline $\mathbf{x}_{ \pm}$SD (tháng) & $3,72 \pm 4,20$ \\
\hline \multicolumn{2}{|c|}{ Thời gian năm viện } \\
\hline $\mathbf{X}_{ \pm}$SD (ngày) & \multicolumn{2}{|c|}{$13,21 \pm 5,39$} \\
\hline
\end{tabular}

Nhân xét: Thời gian trung bình phát hiên bênh là $3,72 \pm 4,20$ (tháng), chủ yếu bệnh nhẩn phát hiện bệnh sớm trong 3 tháng đầu chiếm $66,06 \%$.

Thời gian nằm viện trung bình là $13,21 \pm$ 5,39 (ngày).

\section{Bảng 3. Triệu chứng lâm sàng}

\begin{tabular}{|l|l|l|}
\hline Triệu chứng & Số lượng & Tỷ lệ \\
\hline
\end{tabular}

\begin{tabular}{|c|c|c|}
\hline Rối loạn tiêu hóa & 20 & 18,35 \\
\hline Thay đối hình dạng phân & 7 & 6,42 \\
\hline Mót rặn & 23 & 21,10 \\
\hline Đại tiện nhày máu & 99 & 90,83 \\
\hline Dau bụng & 27 & 24,77 \\
\hline Gầy sút cân & 43 & 39,45 \\
\hline Thiếu máu & 19 & 17,43 \\
\hline Mức độ thiếu máu (n=19) \\
\hline Nặng & 2 & 10,53 \\
\hline Vừa & 2 & 10,53 \\
\hline Nhẹ & 15 & 78,95 \\
\hline
\end{tabular}

Nhận xét: Chủ yếu BN có triệu chứng đại tiện nhày máu, chiếm $90,83 \%$, gầy sút cân chiếm $39,45 \%$. Triệu chứng thiếu máu chủ yếu ở mức độ nhẹ, chiếm 78,95\% trong số những $\mathrm{BN}$ thiếu máu.

Bảng 4. Hình dạng đại thể ung thư trực tràng

\begin{tabular}{|c|c|c|}
\hline $\begin{array}{c}\text { Hình dâng đại } \\
\text { thể }\end{array}$ & $\begin{array}{c}\text { Số lượng } \\
\text { (n) }\end{array}$ & $\begin{array}{c}\text { Tỷ lệ } \\
\mathbf{( \% )}\end{array}$ \\
\hline Sùi & 38 & 34,86 \\
\hline Loét & 16 & 14,68 \\
\hline Loét sùi & 44 & 40,37 \\
\hline Thâm nhiêm & 4 & 3,67 \\
\hline Polyp & 5 & 4,59 \\
\hline Loét thâm nhiêm & 2 & 1,39 \\
\hline Tống & $\mathbf{1 0 9}$ & $\mathbf{1 0 0}$ \\
\hline
\end{tabular}

Nhận xét: Hình dạng đại thể của UTTT chủ yếu là dạng loét sùi $(40,37 \%)$, dạng sùi $(34,86 \%)$, dạng loét $(14,68 \%)$.

Bảng 5. Phân loại mô bệnh học ung thư trực tràng

\begin{tabular}{|c|c|c|}
\hline Phân loại mô bệnh học & \begin{tabular}{|c|} 
Số lượng \\
(n)
\end{tabular} & $\begin{array}{l}\text { Tỷ lệ } \\
(\%)\end{array}$ \\
\hline $\begin{array}{c}\text { Ung thư biếu mô tuyến } \\
\text { (Adenocarcinoma) }\end{array}$ & 95 & 87,16 \\
\hline Ung thư biếu mô tuyến nhày & 14 & 12,84 \\
\hline Tống & 109 & 100 \\
\hline Độ biệt hóa & $\begin{array}{c}\text { Số lượng } \\
\text { (n) }\end{array}$ & $\begin{array}{l}\text { Tỷ lệ } \\
(\%)\end{array}$ \\
\hline Không biệt hóa & 2 & 1,83 \\
\hline Biêt hóa cao & 4 & 3,67 \\
\hline Biết hóa vứa & 91 & 83,49 \\
\hline Biềt hóa kém & 12 & 11,01 \\
\hline Tống & 109 & 100 \\
\hline
\end{tabular}

Nhận xét: Chủ yếu loại ung thư trực tràng là ung thư biểu mô tuyến $(87,16 \%)$. Ung thư biểu mô tuyến nhày chỉ có $12,84 \%$.

Khối ung thư trực tràng chủ yếu có độ biệt hóa vừa $(83,49 \%)$, biết hóa kém chiếm $11,01 \%$, biệt hóa cao $(3,67 \%)$ và không biêt hóa là $1,83 \%$.

Bảng 6. Xâm lấn chu vỉ của ung thư trực tràng

\begin{tabular}{|c|c|c|}
\hline Xâm lấn chu vi & Số lượng (n) & Tỷ lệ (\%) \\
\hline$<1 / 4$ chu vi & 1 & 0,92 \\
\hline $1 / 4-1 / 2$ chu vi & 39 & 35,78 \\
\hline
\end{tabular}




\begin{tabular}{|c|c|c|}
\hline $1 / 2-3 / 4$ chu vi & 59 & 54,13 \\
\hline Toàn bộ chu vi & 10 & 9,17 \\
\hline Tống & 109 & 100 \\
\hline
\end{tabular}

Nhân xét: Khối UTTT xấm lấn chiếm chủ yếu $1 / 2$ - 3/4 chu vi trực tràng $(54,13 \%), 1 / 4$ $1 / 2$ chu vi trực tràng $(35,78 \%)$.

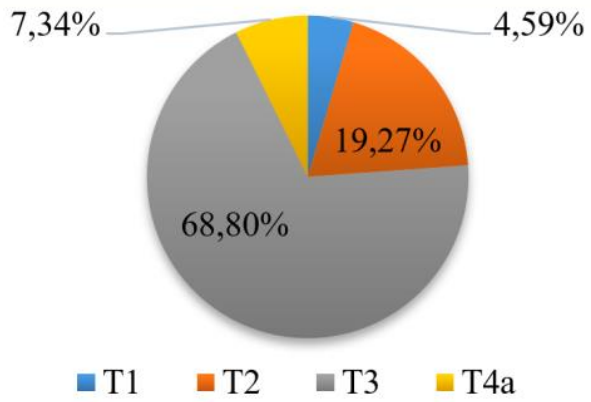

Biểu đồ 1. Giai đoạn xâm lấn ung thư trực tràng Nhân xét: Giai đoạn xâm lấn UTTT T3 chiếm tỷ lệ chủ yếu $(68,80 \%)$, tiếp sau là giai đoạn T2 $(19,27 \%)$, T4a $(7,34 \%)$ và T1 (4,59\%).

\section{Bảng 7. Mức độ di căn hạch}

\begin{tabular}{|c|c|c|}
\hline Di căn hạch & Số lượng (n) & Tỷ lệ (\%) \\
\hline N0 & 65 & 59,63 \\
\hline N1 & 31 & 28,44 \\
\hline N2a & 9 & 8,26 \\
\hline N2b & 4 & 3,67 \\
\hline Tống & 109 & 100 \\
\hline
\end{tabular}

Nhận xét: Di căn hạch $\mathrm{NI}$ có 31 BN chiếm $28,44 \%$, di căn hach N2a có 9 BN chiếm $8,26 \%$, di căn hạch N2b có 4 BN chiếm $3,67 \%$ và chưa có di căn với 65 BN (59,63\%).

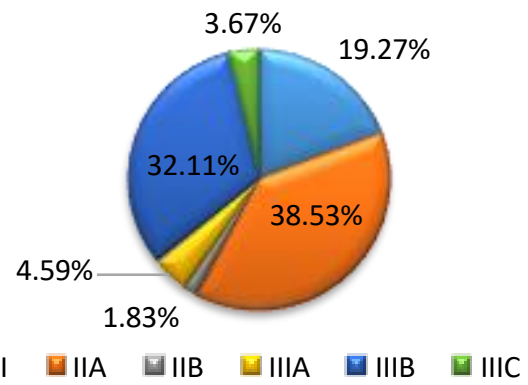

Biểu đồ 2. Chẩn đoán giai đoan bênh UTTT

Nhân xét: Chủ yếu BN UTTT ở giai đoạn IIA $(38,53 \%)$ và IIIB $(32,11 \%)$, các giai đoan khác chiếm tỷ lệ thấp hơn, giai đoạn I $(19,27 \%)$, giai đoạn IIB $(1,83 \%)$, giai đoạn IIIA $(4,59 \%)$ và giai đoạn IIIC $(3,67 \%)$.

\section{BÀN LUÂN}

*Tuổi: Tuổi trung bình mắc ung thư trực tràng là $63,48 \pm 12,22$ (tuổi), độ tuổi chiếm tỷ lệ cao nhất là từ 60 - 69 với 33,94\%, các bệnh nhân UTTT chủ yếu từ 60 tuổi trở lên $(71,55 \%)$.
Nghiên cứu của Kim và cs (2015) về ung thư trực tràng dưới bằng phẫu thuật cắt trực tràng cực thấp ghi nhận tuổi trung bình mắc UTTT là 56 tuổi [8].

Độ tuổi mắc UTTT trong nghiên cứu của chúng tôi cũng tương đồng so với những nghiên cứu trước đây cả ở trong và ngoài nước. Nhận thấy, độ tuổi mắc UTTT thường chủ yếu là trền 60 tuổi.

*Giới tính: Phân bố BN UTTT theo giới tính chủ yếu là nam giới chiếm $66,97 \%$. Trong nghiên cứu của Quách Văn Kiên (2019) cho thấy tỷ lệ mắc UTTT ở nam giới $(62,5 \%)$, nữ giới $(37,5 \%)$ [3]. Nghiên cứu của Kim và cs (2015) có tỷ lệ nam giới mắc UTTT chiếm 62,78\% [8].

Qua các nghiên cứu đều cho thấy tỷ lệ mắc UTTT cao hơn ở nam giới so với nữ giới. Đây là một yếu tố bất lợi cho điều trị phẫu thuật UTTT do đặc điểm khung chậu ở nam giới hẹp hơn so với nữ giới, điều này dẫn tới không gian phẫu tích có nhiều khó khăn hơn, nhất là những trường hợp có khối u lớn.

* Lý do vào viện: Trong nghiên cứu này của chúng tôi, lý do chủ yếu khiến BN phải nhập viện là đại tiện nhày máu $(82,57 \%)$, các triệu chứng khác chiếm tỷ lệ thấp.

Kết quả của chúng tôi phù hợp với ghi nhận của nhiều nghiên cứu của các tác giả khác: Phạm Cẩm Phương (2013) ghi nhận số BN đến bệnh viện vì đi ngoài phân nhầy máu chiếm đa số với 90,9\% [4]. Nghiên cứu của Lê Quốc Tuấn (2020) cũng ghi nhận ý do nhập viện của các BN UTTT là do đại tiện nhày máu với $89,3 \%$ [5]. Như vậy, đại tiện nhày máu là lý do phổ biến và nổi bật nhất khiến $B N$ quan tâm và đến bênh viện để chẩn đoán và điều trị.

*Thời gian mắc bệnh: Nghiên cứu của chúng tôi ghi nhận, thời gian trung bình phát hiện bệnh là $3,72 \pm 4,20$ (tháng), chủ yếu bệnh nhân phát hiện bệnh sớm trong 3 tháng đâu chiếm 66,06\%.Nghiên cứu của Lê Quốc Tuấn (2020) ghi nhận thời gian diễn biến bệnh trước khi vào viện trung bình trong nhóm $\mathrm{BN}$ nghiên cứu là 4,1 tháng, sớm nhất là 1 tháng, muộn nhất là 12 tháng. Trong đó, $80,4 \%$ BN đến viện trong vòng 6 tháng từ lúc có biểu hiện bênh [5].

Điều này chứng tỏ hiểu biết người dân ngày càng nâng cao, bênh nhân thường đến khám tai các cơ sở y tế khá sớm trong vòng 6 tháng đầu từ khi có triêu chứng, thâm chí trong nghiên cứu của chúng tôi còn ghi nhận thời gian tới khám bệnh sớm hơn trong vòng 3 tháng đầu mắc bệnh.

*Triệu chứng lâm sàng: Chủ yếu $\mathrm{BN}$ có triệu chứng đại tiện nhày máu, chiếm 90,83\%; 
gầy sút cân chiếm 39,45\%; Đau bụng chiếm $24,77 \%$; mót rặn chiếm $21.10 \%$; rối loạn tiêu hóa gặp ở 18,35\%; thay đổi hình dạng phân chiếm 6,42\%; thiếu máu gặp ở $17,43 \%$ với chủ yếu là thiếu máu nhẹ.

Nghiên cứu của tác giả Phạm Cẩm Phương (2013) trên 86 BN UTTT điêu trị hóa xạ tiền phẫu cho thấy các triệu chứng phổ biến lần lượt là: đại tiện phân nhầy máu $(94,3 \%)$, cảm giác mót rặn đi ngoài không hết phân $(70,1 \%)$, khuôn phân nhỏ dẹt $(66,7 \%)$, đại tiện $\geq 3$ lần/ngày $(44,8 \%)$ và gây sút cân $(41,4 \%)$ [4]. Nghiên cứu của tác giả Trần Anh Cường (2017) trên 116 BN UTTT được PT cho thây các triệu chứng thường gặp (hớn 50\%) lần lượt là: đi ngoài phân có máu $(93,1 \%)$, thay đổi khuôn phân $(87,1 \%)$, đại tiện khó $(82,8 \%)$, thay đổi thói quen đại tiện $(75,9 \%)$, đi ngoài ngày nhiều lần $(70,7 \%)$, cảm giác mót rặn đi ngoài không hết phân $(54,3 \%)$ [1]. Trong nghiên cứu của Lê Quốc Tuấn (2020), các triệu chứng thường gặp lần lượt là: đại tiện phân nhầy máu $(92,9 \%)$, cảm giác mót rặn đi ngoài không hết phân $(71,4 \%)$, thay đổi khuôn phân nhỏ, dẹt $(66,1 \%)$, thay đổi tăng tân suất đại tiện hàng ngày $>2$ lần $(64,3 \%)$ và sút cân $(53,6 \%)$ [5].

*Đặc điểm giải phẩu bệnh:

Hinh thể UTTT: đại thể của UTTT chủ yếu là dạng loét sùi $(40,37 \%)$, dạng sùi $(34,86 \%)$, dạng loét $(14,68 \%)$. Theo Mai Đình Điểu, bệnh nhân có hình thái u thể sùi chiếm tỷ lệ là $92,5 \%$, thể loét là 3,4\% và thể thâm nhiễm là 4,1\% [2]. Nghiên cứu của Trần Anh Cường (2017) ghi nhận hình thái u thể sùi chiếm tỷ lệ $44,8 \%$, thể sùi loét chiếm tỷ lệ $54,3 \%$ và thể loét $0,9 \%$ [1].

Hình dạng đại thể UTTT trong các nghiên cứu đều cho thấy dạng sùi, loét sùi là chiếm tỷ lệ cao nhất, phổ biến nhất.

Khối UTTT xấm lấn chiếm chủ yễu $1 / 2-3 / 4$ chu vi trực tràng $(54,13 \%), 1 / 4-1 / 2$ chu vi trực tràng $(35,78 \%)$, khối UTTT chiếm dưới $1 / 4$ chu vi và chiếm toàn bộ chu vi lòng trực tràng chiếm tỷ lệ thấp lần lượt là $0,92 \%$ và $9,17 \%$.

Hầu hết các $B N$ đến viện khi khối u đã lớn xâm chiếm nhiều vào chu vi trực tràng, điều này cũng phù hợp với biểu hiện lầm sàng và lý do vào viện chủ yếu là đại tiện nhày máu.

Loại mô bệnh học ung thư trực tràng trong nghiên cứu của chúng tôi chủ yếu loại ung thư trực tràng là ung thư biểu mô tuyên $(87,16 \%)$. Ung thư biểu mô tuyến nhày chỉ có $12,84 \%$. Lê Quốc Tuấn (2020) cho thấy UTBMT thông thường là chủ yếu chiếm $91,1 \%$, UTBMT chế nhầy chiếm $7,1 \%$, có 1 trường hợp ung thư biểu mô tế bào nhẫn chỉ chiếm 1,8\% [5]. Ung thư biểu mô tuyến là dạng ung thư phố biến nhất trong phân loại mô bệnh học ung thư trực tràng, các kết quả nghiên cứu đều ghi nhận kết quả tương đồng nhau.

Độ biệt hóa: trong nghiên cứu này chủ yếu có độ biệt hóa vừa $(83,49 \%)$, biệt hóa kém chiếm $11,01 \%$, biệt hóa cao $(3,67 \%)$ và không biệt hóa là $1,83 \%$.Nghiên cứu của Trần Anh Cường (2017), cho thấy phần lớn $(84,5 \%)$ là biệt hóa vừa, chỉ có tỷ lệ nhỏ $(13,8 \%)$ là biệt hóa cao và biệt hóa kém $(1,7 \%)[1]$. Phần lớn các $B N$ đều có đồ biệt hóa vừa, tiên lượng điều trị $\mathrm{BN}$ còn đáp ứng tốt. UTTT biệt hóa kém có tiên lượng xấu, đặc điểm xâm lấn, di căn nhanh và đáp ứng kém với hóa tri.

Giai đoạn xâm lấn ung thư trực tràng: Trong nghiên cứu này, chúng tôi ghi nhận giai đoạn xâm lấn UTTT T3 chiếm tỷ lệ chủ yểu $(68,80 \%)$, tiếp sau là giai đoạn T2 (19,27\%), T4a (7,34\%) và T1 (4,59\%). Trần Anh Cường (2017), cho thấy tỷ lệ nhiều nhất là pT4 $(48,2 \%)$, tiếp theo là pT3 $(28,5 \%)$ và pT2 $(20,7 \%)$, chiếm tỷ lệ nhỏ là pT1 $(2,6 \%)$ [1]. Các nghiên cứu đều ghi nhận bệnh nhân đến viện khi khối u đã lớn xâm lấn mức độ T3, hiếm khi bệnh nhân phát hiện ở giai đoạn sớm T1, T2. Giai đoạn T3, khối u lớn chiếm lòng trực tràng và gây ra các biều hiện lâm sàng, khiến bệnh nhân phải đến viện thăm khám.

Giai đoạn di căn hạch vừng: Nghiên cứu của chúng tôi cho thấy di căn hạch NI chiếm 28,44\%, di căn hach N2a chiếm 8,26\%, di căn hach N2b chiếm $3,67 \%$ và chưa có di căn với $59,63 \%$. Tỷ lệ BN có di căn hạch vùng ở mức thấp, điều này cũng phù hợp với đặc điểm khối $u$ xâm lấn chủ yếu ở mức T3, do khối u xâm lấn lớn những chưa lan rộng ra xung quanh, do vậy chưa có nhiều khả năng di căn tế bào ung thư vào hạch vùng.

Giai đoạn bệnh UTTT: Phân loại giai đoạn bệnh theo TNM trong nghiên cứu này của chúng tôi, ghi nhận BN UTTT ở giai đoạn IIA (38,53\%) và IIIB $(32,11 \%)$, các giai đoạn khác chiếm tỷ lệ thấp hơn, giai đoạn I $(19,27 \%)$, giai đoạn IIB $(1,83 \%)$, giai đoạn IIIA (4,59\%) và giai đoạn IIIC $(3,67 \%)$. Nghiên cứu của Quách Văn Kiên (2019) về phân loại ung thư theo TNM ghi nhận tỳ lệ phân loại giai đoạn I, II, III trong NC của chúng tôi tương ứng: $25,0 \% ; 36,4 \%$ và $38,6 \%$ [3].

\section{KẾT LUẬN}

Tuổi trung bình mắc ung thư trực tràng là $63,48 \pm 12,22$ (tuổi), chủ yếu là nam giới chiếm $66,97 \%$; độ tuối chiếm tỷ lệ cao nhất là từ 60 69 với 33,94\%. 
Lý do vào viện do đại tiện nhày máu $(82,57 \%)$ chiếm chủ yếu. Thời gian trung bình phát hiện bệnh là $3,72 \pm 4,20$ (tháng), chủ yếu bệnh nhân phát hiện bệnh sớm trong 3 tháng đầu chiếm $66,06 \%$. Triệu chứng lâm sàng đại tiện nhày máu chiếm $90,83 \%$, gây sút cân chiếm $39,45 \%$.

Tổn thương đại thể giảii phẫu bệnh dạng loét sùi $(40,37 \%)$, vi thể UTBM tuyến $(87,16 \%)$ chiếm chủ yếu, phần lớn UTTT có độ biệt hóa vừa $(83,49 \%)$. Đa số chưa có di căn hạch vùng với 65 BN (59,63\%). Mức độ xâm lấn u ở giai đoạn T3 chiếm tỷ lệ chủ yếu (68,80\%).

\section{TÀI LIÊU THAM KHẢO}

1. Trần Anh Cường (2017), Nghiên cứu đăc điểm di căn hạch và kêt quả điều trị phẫu thuật ung thq trực tràng tại bệnh viện K, Luận án Tiến sĩ, Đại học Y Hà Nội.

2. Mai Đình Điểu (2014), Nghiên cứu ứng dung phâu thuât nội soi trong điêu trị ung thư trực tràng, Luận án Tiến sĩ, Đại học Y dược Huế.
3. Quách Văn Kiên (2019), Nghiên cứu ứng dụng phẩu thuâat nôi soi bảo tồn cơ thắt trong ung thư trực tràng giữa và dưới, Luận án Tiến sĩ, Đại học Y Hà̀ nội.

4. Phạm Cẩm Phương (2013), Nghiên cứu hiệu quả của hóa xạ trị tiên phẩu trong điêu trị bệnh ung thư trực tràng giai đoạn xâm lấn, Luận án Tiển sỹ Y học, Trường Đại học Y Hà Nội.

5. Lê Quốc Tuấn (2020), Đánh giá kết quả phẫu thuật cắt đoan và nối máy trong điều trị ung thư trực tràng giữa và thấp, Luận án Tiến sĩ y học, Trường đại học $Y$ Hà Nội.

6. Freddie Bray, Jacques Ferlay, Isabelle Soerjomataram, et al. Global Cancer Statistics 2018: GLOBOCAN Estimates of Incidence and Mortality Worldwide for 36 Cancers in 185 Countries. Ca Cancer J Clin (2018); 68: 394-424.

7. American Joint Committee On Cancer. AJCC Cancer Staging Manual Seventh Edition (2010): $143-164$.

8. Jin C. Kim, Chang S. Yu, Seok-B Lim, et al. Outcomes of ultra-low anterior resection combined with or without intersphincteric resection in lower rectal cancer patients. Int J Colorectal Dis (2015): $1-11$.

\section{CẢM GIÁC ĐAU SAU SỬA SOẠN ỐNG TUỶ BẰNG PHƯƠNG PHÁP QUAY LIÊN TƯC VÀ QUAY QUA LAI}

\section{TÓM TẮT.}

Muc tiêu: Mục tiêu nghiên cứu là đánh giá cảm giác đau sau sửa soạn ống tuỷ bằng phương pháp dùng trâm máy quay liên tục và quay qua lại. Đối tượng và phương pháp: Thử nghiệm lâm sàng với hai nhóm nghiên cứu sửa soạn ống tử bằng phương pháp quay liên tục (ProTaper Next) và quay qua lại (WaveOne Gold) trên 36 răng có chỉ định nội nha ở các bệnh nhân trên 18 tuổi. Đánh giá cảm giác đau trước và sau sửa soạn 1, 2, 7 ngày với bảng câu hỏi và khám lâm sàng. Kết quả: Cảm giác đau trước điều trị, sau sửa soạn 1, 2, 7 ngày giữa hai nhóm quay liên tục và quay qua lại đều khác biệt không có ý nghĩa thống kê. Tình trạng gõ đau trước và sau sửa soạn 7 ngày của hai nhóm cũng khác biệt không có ý nghĩa thống kê. Kết luận: Phương pháp quay liên tục và quay qua lại có hiệu quả tương tự nhau trong việc giảm đau sau sửa soạn ống tuỷ 7 ngày.

Tư khóa: Đau, quay liên tục, quay qua lại, WaveOne Gold, ProTaper Next.

\section{SUMMARY}

\section{PAIN RESPONSE AFTER}

* Đai hoc Y Dượ TP. Hồ Chí Minh

Chịu trách nhiệm chính: Nguyễn Ngọc Phúc

Email: nguyenngocphucdds@gmail.com

Ngày nhận bài: 11/5/2021

Ngày phản biên khoa học: 29/5/2021

Ngày duyệt bài: 21/6/2021/

\section{Nguyễn Ngọc Phúc*, Phạm Văn Khoa* ENDODONTICPREPARATION BY ROTARY AND RECIPROCATING METHODS}

Objectives: The aim of study was to evaluate ofpain response after endodontic preparation by rotary and reciprocating methods. Subjects and methods: A clinical trial with two groups were prepared by rotary andreciprocatingfile systems (ProTaper Nextand WaveOne Gold) on 36 teeth with endondontic indication in patiens over 18 years old. Pain response was assessed before and after preparation 1,2,7 days with questionnaires and clinical examination. Results: Pain responsebetween two groups of rotary and reciprocating methods was not statistically significant difference before andafter preparation $1,2,7$ days. Pain response when percusionoftwo groups was also not statistically significant difference before and afterpreparation 7 days. Conclusion: Rotaryand reciprocatingmethods were similarly effective in reducing pain after 7 days of endodonticpreparation.

Key words: Pain, rotary, reciprocating, WaveOne Gold, ProTaper Next.

\section{I. ĐẶT VẤN ĐỀ}

Đau sau điêu trị nội nha nói chung và đau sau sửa soạn ống tuỷ nói riêng là một trong những tiêu chí rất quan trọng để đánh giá sự thành công của điều trị. Đau sau điêu trị nội nha có thể xảy ra trong vài giờ hoặc vài ngày sau khi điều trị. Mức độ đau cao nhất được ghi nhận 